\title{
Seasonal Variation of Alphitobius diaperinus Population in Broiler Facilities in the Center- North Region of The State of São Paulo
}

-Author(s)
Camargo Neto AF ${ }^{1}$
Tallarico $\mathrm{E}^{1}$
Capriogli MA
Soares VE
Meireles $\mathrm{MV}^{1}$
Silva GS ${ }^{3 *}$
1 Universidade Camilo Castelo Branco,
Campus VIII
2 UNESP - Universidade Estadual Paulista.
Campus de Araçatuba
3 APTA - Agência Paulista de Tecnologia dos
Agronegócios / Pólo Regional do Noroeste
Paulista

\section{Mail Address}

GS Silva

Pólo Regional do Noroeste Paulista/APTA/SAA CP 61

15.500-000. Votuporanga, SP, Brasil

Fone/Fax: (17) 34222423 / 34218148

E-mail: giane@aptaregional.sp.gov.br

\section{- Keywords}

Alphitobius diaperinus, broiler chickens, monitoring, seasonality.

\section{ABSTRACT}

The seasonality of Alphitobius diaperinus population was studied during different seasons during one year, in broiler facilities located in the center-north region of the State of São Paulo. Parasite counting was weekly carried out by the use of traps adapted from the modified model of Arends. During the experimental period, facilities were not submitted to chemical treatment, and the litter was changed between flocks. A lower number of adults and larvae was observed during autumn, with the peak registered in the summer. There was no significant difference between spring and winter averages (adults and larvae), and between spring and summer averages (adults). Average temperatures in the facilities varied from $23.4^{\circ} \mathrm{C}$ (winter) to $27.1^{\circ} \mathrm{C}$ (spring). The environmentally controlled systems used by the broiler industry provide an adequate habitat for $A$. diaperinus development. The continuous monitoring of the population of this parasite is essential for designing control strategies, and this can be accomplished by utilizing the traps used in the present experiment.

\section{INTRODUCTION}

Alphitobius diaperinus parasitism in poultry facilities has become a world-wide problem for the poultry industry (Paiva, 2000; Pfeiffer \& Axtell, 1980; Salin et al., 2003; Steelman, 1996).

The adverse factors resulting from such parasitism are indicated by the fact that this parasite can be a vector, a reservoir, or an intermediate host of important poultry pathogens, such as Cestoda parasites, Eimeria spp., Escherichia coli, Salmonella spp., Aspergillus spp., as well as of Marek's disease, Gumboro disease, avian influenza, and Newcastle disease viruses (Arends, 1987; Safrit \& Axtell, 1984). In addition, this beetle can be used as an alternative food item by chickens, interfering in the birds' development, and thereby causing lack of flock uniformity (Matias, 2000). Morevover, it can have direct action in poultry facilities by destroying equipments inside the poultry house (Turner, 1986)

The environmental conditions in controlled production systems of the poultry facilities (temperature, moisture, and feed present in the litter) provide a favorable habitat for the development and the survival of $A$. diaperinus. The beetles often gather in areas with higher temperature, suitable moisture, and available nutrients (Axtell \& Arends, 1990).

Litter utilized for several grow-outs is a very favorable environment for $A$. diaperinus development, promoting a rapid increase in this beetle's population (Arends, 1987). According to Despins et al. (1989), A. diaperinus adults and larvae prefer to remain in manure habitats with 30 to $40 \%$ of moisture, and leave the manure when moisture level increases to 50 and $60 \%$. 
The favorable temperature for the development and the survival of immature stages of $A$. diaperinus was $31^{\circ} \mathrm{C}$ (Chernaki \& Almeida, 2001). Egg hatching or larval development occurred at $17^{\circ} \mathrm{C}$, and development time (days) was lower for eggs, larvae, pupae, as well as from oviposition to adult emergence at $35^{\circ}$ and $38^{\circ} \mathrm{C}$ (Rueda \& Axtell, 1996).

Biosecurity programs implemented by poultry companies should include measures to control $A$. diaperinus development in poultry houses. Integrated management and chemical control of $A$. diaperinus have been recommended and adopted with the purpose of reducing its population, at a lower cost, lower risk, and higher efficiency.

Understanding the biology, the epidemiology, and the behavior of this parasite is essential to determine control measures in biosecurity programs, and it is a priority for research development.

Monitoring beetle populations in poultry houses is necessary in order to carry out limited control measures, and the use of tube traps is recommended (Axtell \& Arends, 1990).

In the present study, the monitoring of $A$. diaperinus presence in poultry houses located in the center-north region of the State of São Paulo (municipality of Descalvado) was performed during the period of one year, with the determination of its seasonal variation in the autumn, winter, spring, and summer.

\section{MATERIAL AND METHODS \\ Experimental facilities}

This research was performed in naturally infested broiler houses located in the municipality of Descalvado, in the center-north region of the State of São Paulo. The presence of $A$. diaperinus was confirmed by counting adults and larvae in the litter (Thirty-six locations).

During the experimental period of one year, the facility housed six broiler flocks, with a production cycle of 42 days, and an average downtime of 12 days. The facility was not submitted to any chemical treatment during the experimental period, and the litter, consisting of peanut hulls, was changed between flocks.

\section{Experimental evaluation}

Traps were adapted from the modified model of Arends (Silva, 2001), and were used to monitor and to evaluate $A$. diaperinus presence. Thirty six traps were placed at different locations inside of the poultry house for homogeneous evaluation of the entire facility. At weekly intervals, the contents of the traps were collected and the number of adults and larvae of $A$. diaperinus was determined in the laboratory. The temperature inside the facilities was recorded on the same days of traps collections.

\section{RESULTS AND DISCUSSION}

The mean numbers of adults and larvae in the contents of the traps during the different seasons are presented in the Tables 1 and 2. There was a lower degree of infestation of adults and larvae in autumn, which showed lower average infestation $(p<0.05)$ as compared to the other seasons. The degree of parasitism was intensified in the subsequent months; however, averages corresponding to winter and spring were not statistically different ( $p>0.05)$.

The peak of the infestation occurred during the summer (adults: 35,989 and larvae: 435,13 - means), when the larvae infestation was significantly $(p<0.05)$ higher as compared to the other seasons. However, means of adults were statistically equal during spring and summer ( $p>0.05)$.

In the modern poultry industry, temperature and humidity levels are controlled and kept in uniform levels, resulting in a higher comfort for broilers of different ages, continuously providing an ideal habitat for the development of $A$. diaperinus. Chernack \& Almeida (2001) evaluated the effect of constant temperatures $\left(22^{\circ} \mathrm{C}, 25^{\circ} \mathrm{C}, 28^{\circ} \mathrm{C}\right.$, and $\left.31^{\circ} \mathrm{C}\right)$ on immature stages of

\begin{tabular}{|c|c|c|c|c|}
\hline & \multicolumn{4}{|c|}{ Seasons } \\
\hline & $\begin{array}{c}\text { Autumn } \\
26,3^{\circ} \mathrm{C}\end{array}$ & $\begin{array}{l}\text { Winter } \\
23,4^{\circ} \mathrm{C}\end{array}$ & $\begin{array}{l}\text { Spring } \\
27,1^{\circ} \mathrm{C}\end{array}$ & $\begin{array}{c}\text { Summer } \\
25,6^{\circ} \mathrm{C}\end{array}$ \\
\hline Averages & $5,43 \pm 9,01$ & $19,59 \pm 21,86$ & $29,26 \pm 34,13$ & $59,09 \pm 53,76$ \\
\hline Interval of Variation & $0,00-41,25$ & $0,00-66,25$ & $1,33-156,25$ & $0,13-264,44$ \\
\hline Mean & $2,0993 \pm 0,5112$ & $8,5186 \pm 0,6297$ & $16,4206 \pm 0,4760$ & $35,9889 \pm 0,5169$ \\
\hline Interval of Variation & $0,0000-1,6258$ & $0,0000-1,8277$ & $0,3680-2,1966$ & $0,0512-2,4240$ \\
\hline$\sum \log (x+1) / 36^{*}$ & $0.4912^{c}$ & $0.9786^{\mathrm{B}}$ & $1.2411^{\mathrm{AB}}$ & $1.5681^{\mathrm{A}}$ \\
\hline
\end{tabular}

*:Means followed by similar letters are similar by the test of Tukey $(p>0.05)$. LSD - Least Significant Diference $=0.3292$. CV- Coefficient of Variation $=50.16$ 


\section{Camargo Neto AF, Tallarico E, Capriogli MA, Soares VE, Meireles MV, Silva GS}

Table 2 - Means, standard deviations, and results of multiple comparations larvae numbers of Alphitobius diaperinus [data transformed in $\log (x+1)]$ durinbg the different seasons. Descalvado, SP.

\begin{tabular}{|c|c|c|c|c|}
\hline & \multicolumn{4}{|c|}{ Seasons } \\
\hline & Autumn & Winter & Spring & Summer \\
\hline & $26,3^{\circ} \mathrm{C}$ & $23,4^{\circ} \mathrm{C}$ & $27,1^{\circ} \mathrm{C}$ & $25,6^{\circ} \mathrm{C}$ \\
\hline Average & $75,67 \pm 196,27$ & $132,47 \pm 171,06$ & $178,97 \pm 173,95$ & $586,57 \pm 369,94$ \\
\hline Interval of Variation & $0,00-1091,92$ & $0,42-841,67$ & $4,67-738,08$ & $20,25-1351,56$ \\
\hline Geometric Mean & $11,4862 \pm 0,7861$ & $50,2819 \pm 0,7069$ & $100,2755 \pm 0,5349$ & $435,1275 \pm 0,4074$ \\
\hline Interval of Variation & $0,0000-3,0386$ & $0,1513-2,9257$ & $0,7533-2,8687$ & $1,3274-3,1312$ \\
\hline$\sum \log (x+1) / 36^{*}$ & 1.0964 & $1.7100^{\mathrm{B}}$ & $2.0055^{\mathrm{B}}$ & $2.6396^{A}$ \\
\hline
\end{tabular}

*:Means followed by similar letters are similar by the test of Tukey $(p>0.05)$. LSD - Least Significant Diference $=0.3292$.

A. diaperinus, and observed parasite development in the four analyzed temperatures. At $22^{\circ} \mathrm{C}$, longer duration of the development, and a lower parasite survival were observed. The temperature of $31^{\circ} \mathrm{C}$ was the most favorable for the development of immature stages, with higher survival. Rueda \& Axtell (1996) observed that development duration (days) were shorter for eggs, larvae, pupae, as well oviposition to adult emergence time at $35^{\circ}$ and $38^{\circ} \mathrm{C}$.

In the present study, the largest variation in the room temperature was of $3.7^{\circ} \mathrm{C}$, between the winter $\left(23,4^{\circ} \mathrm{C}\right)$ and spring $\left(27,1^{\circ} \mathrm{C}\right)$, which apparently did not interfere in the results. It is emphasized here that there was an expressive increase in $A$. diaperinus population during the winter, confirming that infestation is specifically related to the controlled environmental conditions in poultry houses. Such fact contradicts statements found in the literature, which suggest that the control of this parasite should be planned taking into account the climatic season, such as the winter, due to the fact that the temperature falls, and therefore there is a consequent decrease in the metabolic activity of this parasite.

In this context, monitoring of the local population is an essential tool for designing control strategies, which is consistent with the recommendations available in the literature (Leffer et al., 2002). The control may be achieved by the use of the traps used in the present experiment.

\section{REFERENCES}

Arends JJ. Control, management of the litter beetle. Poultry Digest 1987; 28:172-6.

Chernack AM, Almeida LM. Exigências térmicas, período de desenvolvimento e sobrevivência de imaturos de Alphitobius diaperinus (Panzer) (Coleóptera:Tenebrionidae). Neotropical Entomology 2001; 30:365-8
Axtell RC, Arends JJ . Ecology and management of arthropod pests of poultry. Annual Review Entomology, 1990; 35:101-26.

Despins JL, Turner EC, Ruszler PL. Effects of poultry manure moisture and poultry house construction materials on movements of the lesser mealworm, Alphitobius diaperinus (Panzer) (Coleoptera: Tenebrionidae), a structural insect pest in high rise caged layer houses. Poultry Science 1989; 68:1326-1331.

Matias RS. O controle do cascudinho. Novas perspectivas. In: Anais do Simpósio Brasil Sul de Avicultura; 2000 Abr 3-6; Chapecó. Santa Catarina. p.169-71.

Paiva DP. Cascudinhos: biologia. In: Anais do Simpósio Brasil Sul de Avicultura; 2000 Abr 3-6; Chapecó. Santa Catarina. p135-39.

Pfeiffer RW, Axtel RC. Coleoptera of poultry manure in caged-layer houses in N. Carolina. Environmental Entomology 1980; 9: 21-8.

Safrit RD, Axtell RC. Evaluations of sampling methods for darkling bettles (Alphitobius diaperinus) in the little of turkey and broiler houses. Poultry Science 1984; 63:2368-75.

Rueda LM, Axtell RC. Temperature-dependent development and survival of the lesser mealworm, Alphitobius diaperinus. Medical and Veterinary Entomology 1996; 10:80-6.

Salin C, Delettre YR, Vernon P. Controlling the mealworm Aphitobius diaperinus (Coleóptera: Tenebrionidae) in broiler and turkey houses: field trials with a combined insecticide treatment: insect growth regulator and pyrethroid. Journal of Economic Entomology 2003; 96:126-30.

Silva GS, Veronez VA, Oliveira GP, Borges FA, Silva HC, Meireles MV. Avaliação de métodos de amostragem de "cascudinhos" Alphitobius diaperinus (Panzer) (Coleoptera: Tenebrionidae) em cama de frangos de corte. Semina: Ciências Agrárias 2001; 22:814.

Steelman D. Darkling beetles are costly pests. Poultry Digest 1996; 55:22-23.

Turner JR EC. Structural and litter pests. Poultry Science 1986; 65:644-8. 